\title{
Ecological-based adaptation of agriculture to the soil and climatic conditions in Russian steppe
}

\author{
Gulyanov Yu.A. ${ }^{1}$, Chibilev A.A. ${ }^{1}$, Levykin S.V. ${ }^{1}$, Silantieva M.M. ${ }^{2}$, Kazachkov \\ G.V. ${ }^{1}$, Sokolova L.V. ${ }^{2}$ \\ ${ }^{1}$ Institute of Steppe, Ural Branch of the Russian Academy of Sciences \\ Pionerskaya St. 11, Orenburg, 460000, Russian Federation. E-mail: iury.gulynov@yandex.ru \\ ${ }^{2}$ Altai State University \\ Lenin St.61, Barnaul, 656049, Russian Federation. E-mail: msilan@mail.ru
}

Received: 14.08.2019. Accepted: 26.09.2019

\begin{abstract}
The article substantiates the urgency of environmental optimization of steppe land use, aimed at overcoming the acute challenges of our time, associated with the depletion of natural resources, climate change and food tension. The article analyzes the main problems of nature use, typical for steppe regions of Russia at a modern geoecological state of landscapes. The transboundary character of the territory under consideration is noted and the evolution of its landscapes under the influence of natural and anthropogenic factors, which make the study of the issues of rational use of natural resources and sustainable development of steppe regions actual, is described. The attention is focused on the significant participation of the mesoregion under consideration, which has the main share of the area of spread of black earths, in the production of agricultural products and strategic importance for the sustainable functioning of the Russian economy. Correlation-regression relations of the main ecological factors with productivity of grain agrocenoses are analyzed and ecologically oriented methods of increasing the efficiency of bioclimatic resources use of the mentioned territory are substantiated. Promising technological solutions, the introduction of which guarantees the maintenance of social and food security, will ensure the inexhaustible use of soil and land resources and reduce the anthropogenic impact on natural ecosystems, the preservation of biological diversity in the steppe regions in their agricultural use. The conclusion is made about the possibility of increasing the economic feasibility of crop production and noticeable soil-restoring and medium improving effects, new reserves to meet the needs of the modern generation and ensure social justice, while reducing the risks of impoverishment of the environment and limiting the life opportunities of future generations.
\end{abstract}

Key words: Optimization of steppe land use; Natural ecosystems; Environmental factors; Landscape adaptive farming

\section{Introduction}

One of the territories of the country, where ecological problems are especially acute, is the steppe zone, which is the most developed in economic terms.

The territory under study is characterized by the zonal integrity of the continuous steppe massif and administratively includes 22 subjects of the Russian Federation in 6 federal districts (11 regions - Belgorod, Voronezh, Volgograd, Rostov, Orenburg, Samara, Saratov, Kurgan, Chelyabinsk, Novosibirsk, Omsk); 8 republics - the Republic of Adygea, the Republic of Kalmykia, the Republic of KabardinoBalkaria, the Republic of Ingushetia, the Republic of North Ossetia-Alania, the Chechen Republic, the Republic of Bashkortostan and the Republic of Crimea; 3 regions - the Krasnodar, Stavropol and Altai). The region covers an area of 1651.5 thousand $\mathrm{km}^{2}$ ( $9.7 \%$ of the Russian Federation's territory), which is home to more than 48.2 million people (Chibilev (yr.), 2016).

The transboundary nature of the territory under consideration and the evolution of its landscapes under the influence of natural and anthropogenic factors make the study of the issues of rational use of natural resources and sustainable development of steppe regions a topical issue. Due to its transboundary nature, the presence of a large number of latitudinal economic, social, ethnocultural and historical ties between Russia and the whole of Northern Eurasia, the steppe zone is one of the key zones in the Russian Federation in geographical and communication sense.

The structure of steppe nature use that has developed over a long period of time has determined a significant degree of transformation and fragmentation of natural geosystems and weakened their structural and functional stability. Agricultural development has led to a radical change in the flat terrain, reflecting the zonal features of landscapes and playing an important role in the formation of climate. The most important factors of the negative transformation of landscapes of the steppe zone were also overgrazing of cattle, extermination of forests, formation of unclaimed land fund, accompanied by soil degradation, desertification, and reduction of biological diversity. These problems, which need both theoretical generalization and practical solutions, are topical scientific problems of great social and economic importance in the steppe zone of the country (Chibilev, 2016).

The mesoregion under consideration covers a significant part of the agricultural belt of the country and has the main share of the area of spread of black earths. On $14 \%$ of the total area of the country, in regions of a steppe zone of Russia about $80 \%$ of the sowing areas of agricultural crops and to $65 \%$ of a livestock of a cattle are concentrated. About $70 \%$ of Russian agricultural production is produced here (Chibilev et al., 2018). The Stavropol Krai, the Republic of Kalmykia and the Orenburg Oblast (88.492.3\%) have the largest share of agricultural land under consideration, while the Altai Krai has the largest area of 11.5 million hectares. The same subject of the Russian Federation is the leader in terms of agricultural land area (10.6 million hectares).

In accordance with this, the purpose of our research was to identify the links between the main environmental factors and the productivity of grain agrocenosis in the steppe belt of Russia and the justification of environmentally-oriented methods of effective use of bioclimatic resources of the area. 


\section{Methods}

Methods of field, landscape researches, correlation-regression analysis and statistical material processing are used.

- In steppe regions of the Russian Federation, at a modern geo-ecological condition of landscapes, in our opinion, following general problems of nature use are allocated:

- Anthropogenic fragmentation of conditionally-natural (pastures and hayfields) and reference (natural reserves) steppe landscapes, "islandization" of ecosystems, lack of ecological connectivity of the space;

- Degradation of steppe herbaceous biocoenoses as a result of excessive grazing, anthropogenic load, clogging of landfills and industrial wastes with products;

- Anthropogenic desertification in the form of formation of extensive anthropogenic-modified wastelands on unused lands;

- Decrease of natural fertility of lands as a result of application of soil-cost agricultural technologies;

- Ubiquitous destruction of centers of increased landscape and biological diversity, refugia, formation and aggressive spread of centers of foreign biota elements;

- Implementation of unreasonable reclamation measures;

- Activation of natural fires and related risks of environmental and human-made crisis situations;

- Pollution of natural environment (water, air, soil), formation of technogenic pollution areas, especially in oil and gas production;

- Ecological and hydrological problems related to the growth of water demand, regulation of river runoff and climate change;

- Formation of unclaimed land fund and seizure of land by unscrupulous land users, accompanied by soil degradation and decrease of biocoenosis stability.

Degradation processes and reduction of natural soil fertility as a result of application of soil-cost technologies in crop production are clearly visible in all regions of the steppe zone. The extensive farming systems used for many decades, which were mainly soil- and anti-landscape in nature, which impeded the adaptation of agriculture to soil, climate and landscape conditions, have led to the degradation of agricultural land, increased aridity of the territory, reduced productivity of fields, meadows and pastures (Kiryushin, 1999; Sokolova et al., 2019).

Meanwhile, it is well known that high crop yields can be obtained only in such conditions when the arrival of photosynthetically active radiation (PAR), soil and air temperature, water availability of crops, mineral nutrition of plants and other environmental factors do not prevent the intensive formation of plant biomass and the formation of economic - useful part of the harvest. In the majority of soil-climatic zones of the Russian Federation for traditional (zoned) crops (varieties) the arrival of PAR does not limit these processes - yield is most often limited by climatic conditions. The climate determines the geographical distribution and efficiency of cultivation of all agricultural crops (Shatilov, Stolyarov, 1986). to use productively the potential of plants it is necessary to take into account the peculiarities of the climate in a particular cultivation zone for a particular crop (Gulianov et al., 2010; Polyakov et al., 2016). For these purposes, quantitative indicators of the impact of environmental factors on crops are established, and cultivation technologies are adapted to their biological characteristics and landscape conditions.

As was theoretically and practically approved, the upper limit of yield is determined by the number of incoming FAR and the coefficient of its use. In the regions of the steppe zone of the European part of Russia this factor of the environment allows to grow the yields of traditional crops significantly (by 1.5 - 2.0 times) higher than those obtained in production. The reason lies in providing plants with moisture - at sufficient supply of plants with energy of sunlight and nutrients (in regulated conditions of mineral nutrition) in the areas of insufficient and irregular humidification, the maximum possible value of yield is determined by moisture availability of crops.

\section{Results and Discussion}

It is established that in the context of the regions of the steppe zone of Russia, the moisture content of crops varies significantly, which is most obvious with respect to precipitation. The largest annual average precipitation is found in the foothills of the republics of North Ossetia-Alania $(929 \mathrm{~mm})$, Ingushetia $(720 \mathrm{~mm})$, Kabardino-Balkaria Republic (724 mm), Krasnodar Territory $(718 \mathrm{~mm})$ and Rostov Region (643 mm). In Belgorod (605 mm), Voronezh (587 mm), Samara (557 mm) Oblasts and Stavropol Krai $(556 \mathrm{~mm})$ the precipitation availability is $131-162 \mathrm{~mm}(13.1-22.5 \%)$ lower. The greatest deficit of precipitation is observed in the Altai Territory $(431 \mathrm{~mm})$, Omsk (415 mm), Kurgan $(406 \mathrm{~mm})$, Orenburg (364 mm), Volgograd (347 mm) regions and the Republic of Kalmykia $(349 \mathrm{~mm})$. According to the data presented, the coefficient of variation of this indicator is more than $60 \%$. This introduces significant adjustments in the formation of field crop yields and, of course, should be reflected in the transformation of agricultural technologies to zonal soil and climatic conditions (Bulletins ..., 2018, Regions of Russia ..., 2018).

Cereals and legumes occupy the largest share in the structure of sown areas of all steppe regions of Russia without exception and most objectively reflect the productivity of fields. 


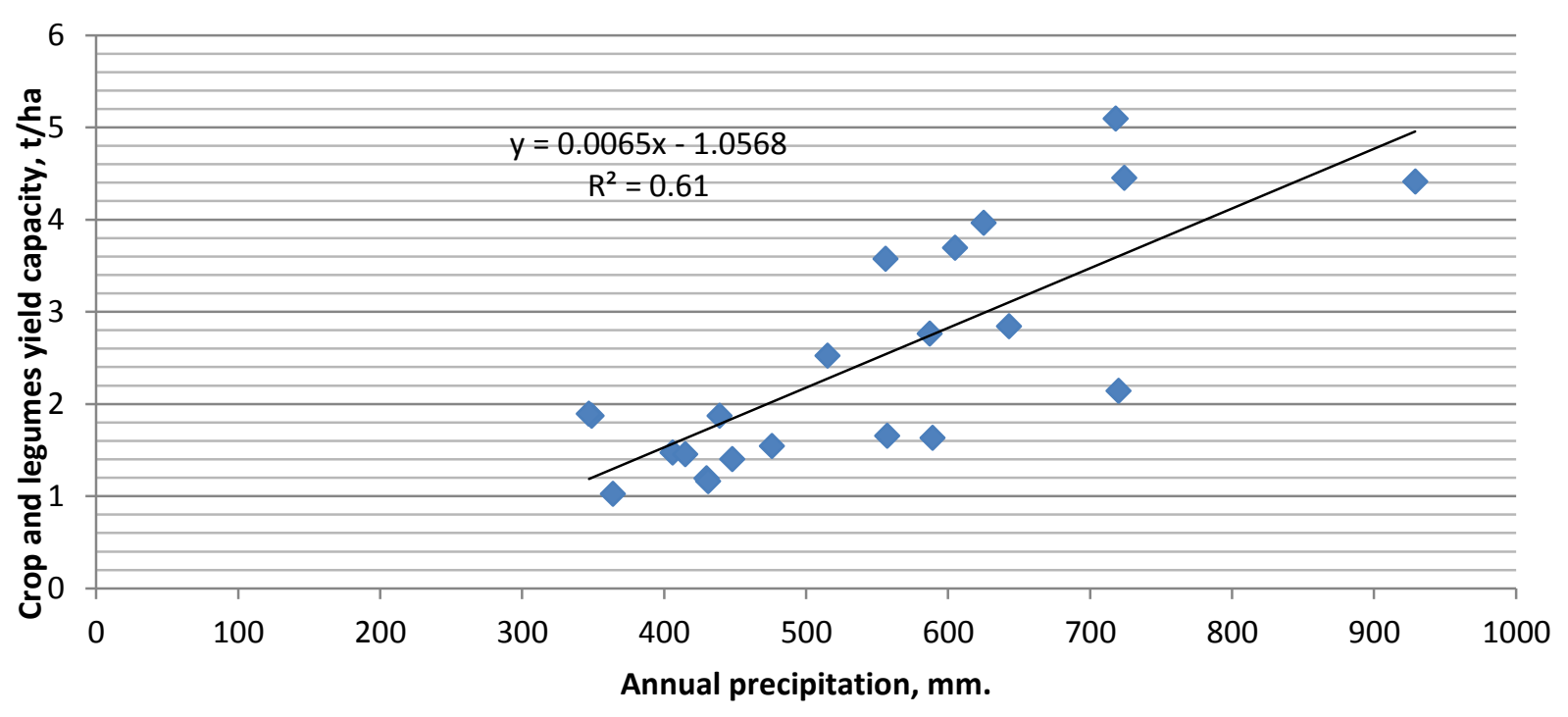

Figure 1. Dependence of grain and legume yields on average annual precipitation

Correlation and regression analysis (Dogekhov, 1985) of their average annual yield (over the period of 2005-2017) revealed a strong correlation $(r=0.78)$ with the amount of precipitation, which determines $61.0 \%$ of its dispersion at a fixed position of other factors. Dependence is described by the pairwise regression equation $y=0.006 x-1.056$ (Figure 1 ).

In the more arid regions of the steppe zone of European Russia, the relationship between these values is even stronger ( $r=0.84$ ). The area of the lands covered with forest in the regions of the steppe zone of Russia in the all-Russian scale is relatively small and makes 69719,8 out of 870700 thousand hectares $(8,0 \%)$. The most acute deficit of forest lands is felt in the dry steppes of European Russia, where their area is only 5210.8 thousand hectares or $0.6 \%$.

A similar situation can be traced with regard to the forest cover of the steppe zone regions of the UTR - with an average forest cover of $46.4 \%$ in the country it is much lower and makes up only $6.2 \%$. The situation is more favorable in Krasnodar Krai (20.2\%) and Samara Oblast (12.8\%). In the remaining European regions, forest cover is significantly lower than $10.0 \%$, and the lowest indicators are found in the Republic of Kalmykia (0.2\%), Stavropol Krai (1.6\%), Rostov (2.4\%), Volgograd (4.2\%) and Orenburg $(4.6 \%)$ Oblasts.

Average correlation between grain yield and forest cover of steppe territories was revealed $(r=0.51)$. At the same time, the moisture- and soil-saving value of tree plantations has been repeatedly proved by time and is not subject to doubt, especially in windy steppe areas of European Russia, with scarce precipitation.

Against this background, the volume of reforestation works looks very unconvincing, which for the period from 2005 to 2017 amounted to only $7.5 \%$ of the total volume of the country - 64.34 out of 851.7 thousand hectares per year. Encouraging results are shown by the foresters of Bashkortostan, Altai Krai, Novosibirsk, Omsk, Kurgan and Chelyabinsk Oblasts, who carried out reforestation works on the area of $12.8-12.7-6.7-4.8-4.3-3.3$ thousand hectares per year. On the forest lands of the steppe regions of European Russia (Republic of Kalmykia, Stavropol Krai, Rostov Oblast), which are acutely in need of reforestation, such works were carried out in incomparably smaller volumes during this period.

Our previous studies conducted with different field crops on the black soils of the southern Orenburg Urals revealed that the lack of available mineral nutrients with sufficient heat and light significantly limits their yield and increases the consumption of scarce moisture resources for crop formation (Gulianov, 2006). The results of the studies described now became another evidence of this statement.

As it is known, the main sources of replenishment of the elements of mineral nutrition by the harvests are organic and mineral fertilizers. In our country cultivation of field crops on steppe black earth soils was traditionally based on mobilization of their high natural fertility. Intensification of agriculture was based on technogenic factors, which was invariably accompanied by soil degradation. Therefore, the main reason for the decrease in the fertility of chernozems is inextricably connected with the decrease in the content of organic matter, intensive mobilization of the most valuable compounds, as a result of which the agrophysical properties of the soil deteriorate and its water regime changes (Pichugin and Morozova, 1999).

Such traditions of wasteful use of soil resources and neglect of mineral and organic fertilizers, although often due to objective economic reasons, are still preserved in Russian agriculture. This is also evident in some regions of the steppe zone of Russia. If in general the norms of mineral fertilizers application per 1 hectare of sown area (significantly lower than the world indices!) in comparison with the all-Russian ones are quite convincing - 35.2 against $38.1 \mathrm{~kg} /$ hectare of active substance for the period of 2005 2017 or $92.4 \%$, then in the context of regions there is a significant variation.

The most responsible attitude to the replenishment of soil resources with elements of mineral nutrition (according to the results of 2017 ) is noted in Krasnodar Krai (134.4 kg/ha of active substance), the Republic of Adygea (124.1 kg/ha), Belgorod Oblast (108.1 $\mathrm{kg} / \mathrm{ha})$, Stavropol Krai (95.7 kg/ha), Voronezh (85.5 kg/ha) and Rostov (80.3 kg/ha) Oblasts, Kabardino-Balkarian Republic (83.9 $\mathrm{kg} / \mathrm{ha}$ ), Kabardino-Balkarian Republic ( $83.9 \mathrm{~kg} / \mathrm{ha}$ ). In other territories, mineral fertilizers are applied in much smaller amounts. If in Bashkortostan, Kurgan, Volgograd and Samara oblasts this indicator exceeds $20.0 \mathrm{~kg} / \mathrm{ha}$, in Altai Krai it is $12.1 \mathrm{~kg} / \mathrm{ha}$, in Republic of Kalmykia - $11.4 \mathrm{~kg} / \mathrm{ha}$, in Saratov oblast $-9.9 \mathrm{~kg} / \mathrm{ha}$. At the end of 2017, farmers in the Orenburg region applied the least amount of mineral fertilizers per 1 hectare of sown area $-2.5 \mathrm{~kg} / \mathrm{ha}$, which is almost 20 times lower than the average for the steppe zone of Russia. Meanwhile, correlation and regression analysis of the average annual yield of grain and legume crops revealed a strong correlation $(r=0.88)$ with the amount of mineral fertilizers applied, which determines $78.6 \%$ of its dispersion. Dependence is described by the equation of pairwise regression $y=0.032 x+1.296$ (Figure 2 ). 


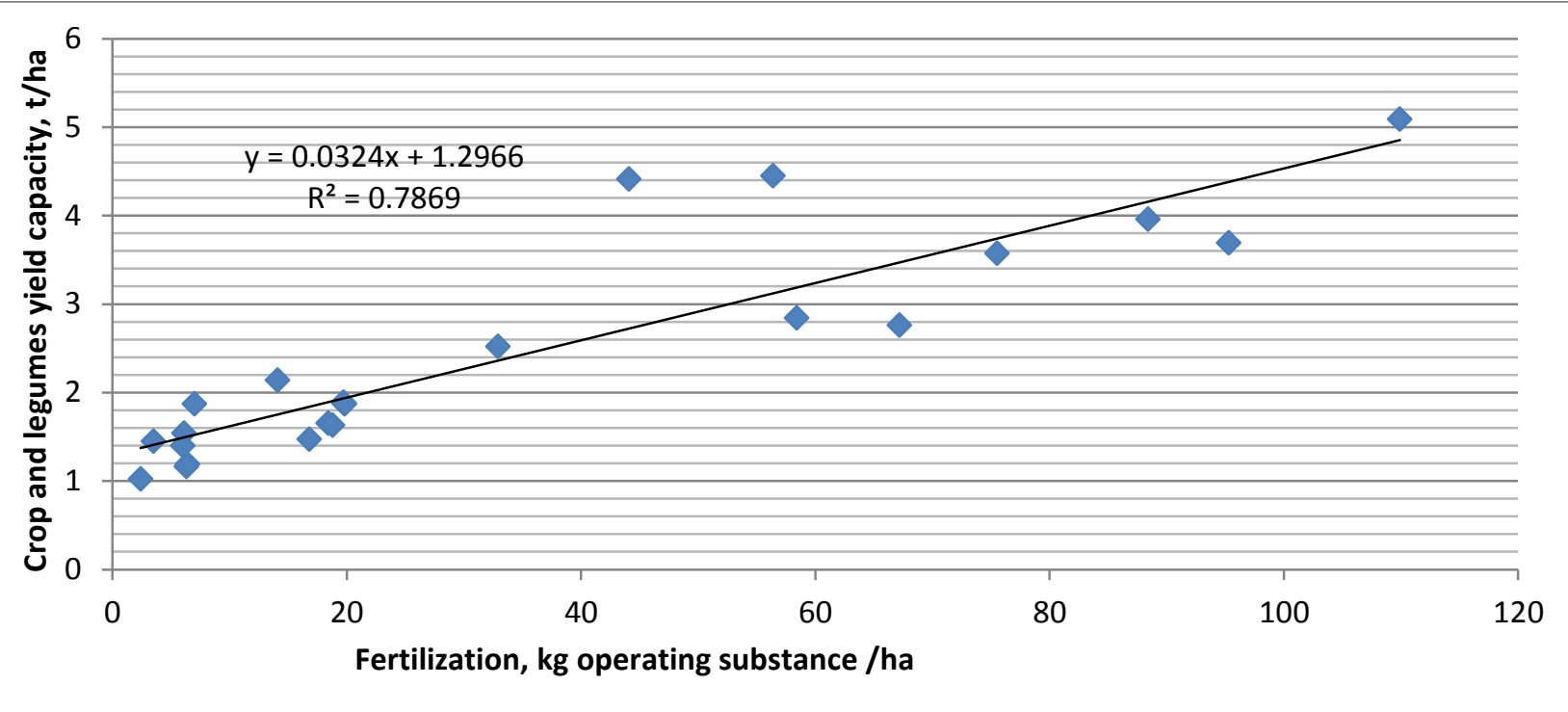

Figure 2. Dependence of grain and legume crop yields on mineral fertilizer application.

The situation with the application of organic fertilizers, or rather, with almost complete absence of fertilizers in some regions, causes some bewilderment. For example, with almost equal number of cattle in Belgorod oblast (223.9 thousand heads) apply 8.4 t/ha of organic fertilizers, and in Samara oblast (228.6 thousand heads) - only $0.3 \mathrm{t} / \mathrm{ha}$. In Stavropol Krai, with almost equal feed consumption per conditional head, from 319.1 thousand cattle bring 4.0 t/ha, and in Volgograd Oblast from 297.0 thousand incomparably less, only $0.02 \mathrm{t} / \mathrm{ha}$ of sown area. Practically no organic fertilizers are applied in the Orenburg Oblast - $0.1 \mathrm{t} / \mathrm{ha}$ from the second largest cattle herds in the steppe zone of the UTR ( 568.5 thousand heads), Saratov Oblast (0.1 t/ha from 424.9 thousand heads). At the most numerous herd of cattle in 592, 7 thousand heads and the highest feed consumption per 1 conditional head ( 2.86 tons of feed units) in the Rostov region only 0.5 tons/ha of organic fertilizers are exported to the fields.

Special attention should be paid to the analysis of data on the financial support of scientific support of the agricultural sector.

It is well known that in modern agricultural production, for the successful implementation of the "Strategy for Scientific and Technological Development of the Russian Federation" (Strategy..., 2016) priorities include the development of breakthrough agrotechnologies capable of ensuring technological independence and food security of the state. They are based on the digital transformation of agriculture, the widespread use of remote sensing data for the needs of agriculture, the implementation of intelligent digital technologies in the management of agro-industrial complex within the framework of complex scientific and technical projects "Digital land use" and "Digital technologies in the management of agro-industrial complex" - "Smart garden", "Smart field", "Smart farm" and "Smart greenhouse". As a basic basis for the implementation of these projects are considered the restoration of the state institute of land resources, the formation of ecological frameworks of the territory, landscape and ecological territorial planning, harmonization of crop and livestock industries.

It is quite obvious that the effective transition from traditional agriculture to innovative eco-friendly "digital technologies" requires training of highly qualified personnel and sufficient financial support of scientific support in the form of scientific teams of agricultural universities and research institutions (Gulianov, Chibilev, 2019). Correlation and regression analysis of the average annual values of grain and legume yields revealed a strong correlation $(r=0.93)$ with the internal expenditures of the regions for research and development per 1 hectare of sown area (Figure 3), which determines $79.8 \%$ of its dispersion. The dependence is described by the pairwise regression equation $y=0.014 x=0.780$.

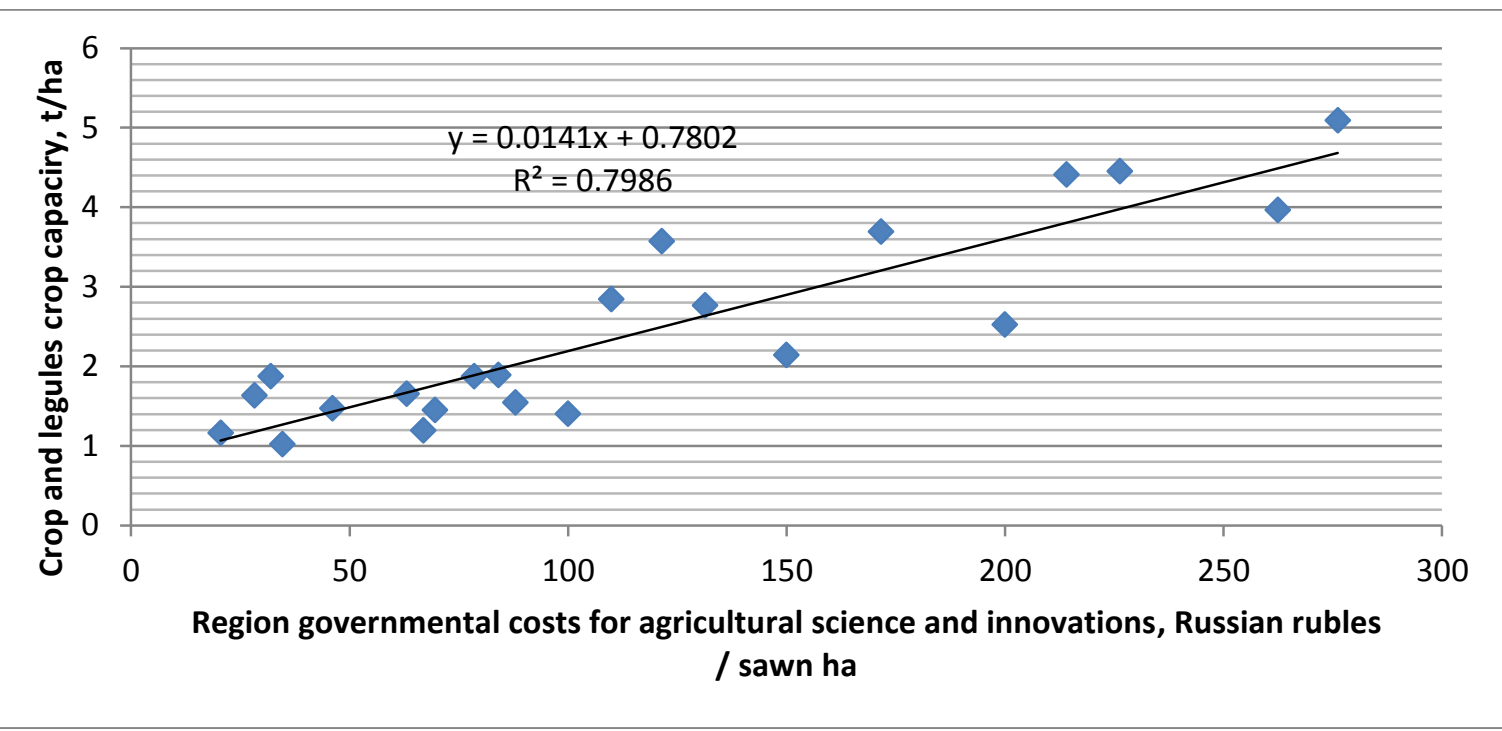

Figure 3. Dependence of cereal and legume crop yields on the internal costs of agricultural research and development in the regions 
The largest of the steppe regions of Russia's internal costs of research and development in agricultural sciences (1,010.4 million rubles), including 1 hectare of sown area (276.2 rubles), in 2017 were noted in the Krasnodar region, which received the highest yield of grain and leguminous crops - 5.74 tons / ha.

The following regions of the European territory of Russia are in descending order of yield: Belgorod region - 171.6 rub/ha and 4.8 t/ha; Stavropol region - $212.5 \mathrm{rub} / \mathrm{ha}$ and $4.27 \mathrm{t} / \mathrm{ha}$; Voronezh region - $131.4 \mathrm{rub} / \mathrm{ha}$ and $3.94 \mathrm{t} / \mathrm{ha}$; Rostov region - $109.9 \mathrm{rub} / \mathrm{ha}$ and $4.04 \mathrm{t} / \mathrm{ha}$. The lowest internal costs of scientific research and development per 1 ha of sown area in 2017 were noted in the Altai Territory (20.5 rubles) and the Orenburg Region (34.6 rubles). In these regions, in the rather high yielding 2017, the lowest yield of grain and legume crops was obtained -1.34 and $1.58 \mathrm{t} / \mathrm{ha}$, respectively.

We believe that the identified links between the main environmental factors and the productivity of grain agrocenosis in the steppe zone of Russia are a significant basis for the development of regional technological and financial policies in the field of agriculture, the transition to resource-saving (primarily moisture-saving) landscape - adaptive technology with guaranteed scientific support.

\section{Conclusion}

Based on the results of many years of field and agrolandscape expeditionary research in the Orenburg, Samara, Saratov, Volgograd regions, Krasnodar and Altai Krai, the Republic of Bashkortostan and other areas of the steppe belt of Russia, correlation and regression analysis of statistical reporting data, we believe that the agricultural use of steppe agro-landscapes allows for the implementation of an ecologically-based approach in the direction of effective use of bioclimatic resources in the following techniques. Maintaining an optimal ratio of different types of agricultural land and creating a land reserve for the formation of landscape and ecological framework, the development of a continuous network of territorial protection of landscapes, preservation of standards of undisturbed nature as a landscape and ecological reserve, geo-ecological counterweight and laboratories of nature. It is expedient to develop low-yielding and unused lands as pastures, to build a forest-reclamation framework by restoring the diversity of natural forest cover in order to create the most sustainable, ecologically functional and economically less costly forest areas (Levykin et al., 2017). Reanimation of field-protective forestation, planting of field-protective forest belts on the principle of development of the unique Kulunda steppe (6.4 million hectares!), carefully afforested in the 50-70 years of the last century in accordance with scientifically sound requirements for the protection of fields from destructive winds. Even today, after years of oblivion, the Kulunda forest belts represent a grandiose wind-protecting shield that prevents soil particles from drifting, promotes even distribution of snow in the inter-band space and its greater accumulation, increases the relative humidity of the air, reduces the intensity of evaporation, especially in years with adverse weather conditions (Paramonov, 2011).

Introduction of agro-landscape turnover of lands, promoting their self-rehabilitation and natural processes of fertility restoration through the formation of ecological frameworks of the territory, landscape and ecological territorial planning, harmonization of crop and livestock sectors. Use only elite soils for agriculture, which do not need additional land reclamation, in order to restore steppe ecosystems, landscape and biological diversity. Low-productive arable lands with unprofitable production of plant-growing products released under this approach should be transferred to hay-pastoral lands, which will allow to create a zone of harmonious combination of gentle farming and highly efficient cattle breeding in steppe areas, maintain biological diversity of steppe inhabitants, form shelters for birds, mammals, insects, rare and endangered plant species.

Implementation of intelligent digital agricultural technologies of "smart land use" based on soil-rehabilitation crop rotations with perennial grasses, zero tillage (No-till), targeted differential application of mineral, organic fertilizers and pesticides for climateprotected crops of field crops, mulching, sowing of soil loosening crops, break crops, strip plantation crops and phytomelioration, inclusion of elements of contour-landscape, precision farming, wide use of remote sensing data, etc.

Competent practical implementation of the above mentioned methods presupposes increase of economic expediency of crop production and noticeable soil restoring and medium improving effect, opens new opportunities for satisfaction of needs of modern generation and provision of social justice at the same time reducing risks of environment impoverishment and limitation of life opportunities of future generations.

\section{Acknowledgements}

This work was supported by the Russian Science Foundation's project No. 17-17-01091 "Strategy for spatial development of steppe and post-Virgin Land Campaign regions of European Russia on the basis of framework territorial planning and development of continuous ecological networks".

\section{References}

Bulletin on the state of agriculture (electronic versions). (2018). Catalogue of publications: Federal State Statistics Service. Available from: http://www.gks.ru/wps/wcm/connect/rosstat main/rosstat/ru/statistics/publications/catalog/doc 1265196018516/ (Accessed on 09.10.2019). (in Russian).

Chibilev, A.A. (2016). Optimization of the structure of the land fund and development of a network of protected areas in the steppe zone of Russia. Orenburg: Steppe Institute of the Ural Branch of the Russian Academy of Sciences (in Russian).

Chibilev, A.A. (2019). Prospects of integration of the "digital land use" in landscape adaptive farming of the steppe zone. Problems of regional ecology, 2, 32-37. (in Russian).

Chibilev, A.A. (Jr.). (2016). Analysis of the use of land resources in the aspect of formation of socio-economic potential and assessment of indicators of sustainable development of the steppe regions of the Russian Federation. Optimization of the structure of the land fund and development of a network of protected areas in the steppe zone of Russia. Orenburg. Steppe Institute of the Ural Branch of the Russian Academy of Sciences (in Russian).

Chibilev, A.A., Chibilev (yr), A.A., Rudneva, O.S., Sokolov, A.A., Padalko, Yu.A., Meleshkin, D.S., Grigorevsky, D.V. (2018). Problems of sustainable development of social and economic geosystem stem zone in the Russian Federation. Orenburg: Steppe Institute of the Ural Branch of the Russian Academy of Sciences (in Russian).

Dospekhov, B.A. (1985). Field experience methodology (with basics of statistical processing of research results). Moscow: Agropromizdat (in Russian).

Gulianov Yu.A. (2006). Adaptation of technological methods of winter wheat cultivation in the steppe regions of the Southern Urals. Agrobiological features and parameters of models of highly productive agrocenosis of field crops in the arid conditions of the Southern Urals: a collection of scientific papers. Orenburg: Publishing Center of Orenburg State Agrarian University (in Russian). 
Gulianov, Yu.A., Dosov, D.Zh., Umarova, S.V. (2010). Efficiency of the bioclimatic resources use at the winter wheat growing in the Orenburg region (in Russian). Izvestia of the Orenburg State Agrarian University, 2, 48-50 (in Russian).

Kiryushin, V.I., Belkov, G.I. (1999). Scientific bases of the adaptive-landscape systems of agriculture (in Russian). Sustainable agriculture system of the Orenburg region. Orenburg: Orenburg Book Publishing House (in Russian).

Levykin, S.V., Kazachkov, G.V. (2017). Steppe question of Russia: from steppe studies to degree studies. Successes of the modern science and practice, 3(6), 211-220. (in Russian).

Paramonov, E.G. (2011). State of protective forestation in the Altai Territory. Izvestiya of Altai State University, 8(82), 48-52. (in Russian).

Pichugin, A.P., Morozova, E.V. (1999). Yield of winter wheat at complex increase of chernozems fertility. Direction of stabilization of development and exit from crisis of agrarian and industrial complex in modern conditions. Voronezh (in Russian).

Polyakov, D.G., Khalin, A.V., Bakirov, F.G., Nesterenko, Yu.M., Vasilieva, T.N. (2016). Moisture dynamics of the black earths in the southern Orenburg region during the direct sowing and the main soil treatment (in Russian). Bulletin of the Orenburg Scientific Center of the Ural Branch of RAS, 4, 13. (in Russian).

Regions of Russia. Socio-economic indicators. (2018). R32 Statutory collection Rosstat. Moscow. Available from: http://www.gks.ru/wps/wcm/connect/rosstat -main/rosstat/ru/statistics/publications/catalog/doc 1138623506156/ (Accessed on 01.10.2019). (in Russian).

Shatilov, I.S., Stolyarov, A.I. (1986). Yield Programming Guide. Moscow. Rosselkhozizdat (in Russian).

Sokolova, L.V., Silantieva, M.M., Belyaev, V.I. (2019). Factors causing the reduction of steppe ecosystems of the Altai Territory. The Turkic-Mongolian World of the Big Altai: Historical and Cultural Heritage and Modernity. Proceed. First Int. Altaitical Forum, BarnaulGorno-Altaisk, 12-14 September 2019. Barnaul. Altai State University Publishing (in Russian).

Strategy for Scientific and Technological Development of the Russian Federation (approved by the Decree of the President of the Russian Federation of December 1, 2016 № 642. Available from: http://www.kremlin.ru/acts/bank/41449/ (Accessed on 14.09.2019) (in Russian).

\section{Citation:}

Gulyanov Yu.A., Chibilev A.A., Levykin S.V., Silantieva M.M., Kazachkov G.V., Sokolova L.V. (2019). Ecological-based adaptation of agriculture to the soil and climatic conditions in Russian steppe. Ukrainian Journal of Ecology, 9(3), 393-398.

This work is licensed under a Creative Commons Attribution 4.0. License 